\title{
Role of Transformational Leadership in Employee's Performance with Mediating Role of Job Satisfaction in Health Sector of Pakistan
}

\section{Shahzad Naeem ${ }^{1 *}$ and Benish Khanzada ${ }^{2}$}

${ }^{1}$ Riphah International University, Islamabad, Pakistan

${ }^{2}$ Quetta Institute of Medical Sciences, National University of Medical Sciences (NUMS), Pakistan

*Corresponding author: Shahzad Naeem, Riphah International University, Islamabad, Pakistan, Tel: +00923335491914; E-mail: shahzadflyer@yahoo.com

Received date: December 30, 2017; Accepted date: January 06, 2018; Published date: January 15, 2018

Copyright: $\odot 2018$ Naeem S, et al. This is an open-access article distributed under the terms of the Creative Commons Attribution License, which permits unrestricted use, distribution, and reproduction in any medium, provided the original author and source are credited.

\begin{abstract}
This research explores the association among transformational leadership, employee performances and also investigates the mediation of job satisfaction in the association of transformational leadership as independent variable and employee performance as dependent variable in health sector of Pakistan. Research data was collected; using questionnaire total 152 respondents participated in the study. From data analysis, it was concluded that the transformational leadership positively influences employee performance in the health sector of Pakistan. Job satisfaction as mediator was assessed by applying mediated regression analysis. It was found that job contentment mediated the affiliation between relation of transformational leadership as independent variable and employee performance as dependent variable.
\end{abstract}

Keywords: Transformational leader; Employee’s performance; Job satisfaction

\section{Introduction}

In Pakistan health sector is considered one of the major service sectors. General health of Pakistani people is positively affected by the effectiveness of this sector. Similar to any other organization, the organizational effectiveness of health sector heavily depends on the leadership. Keeping in view the advancement in information technology and organizational structure as well as culture, the importance of leadership has enhanced in organizations. In management leadership is most discussed but at the same time remained most confusing topic. Researchers have different views about the leader's role and their effectiveness in success or failure of any industry, project or organization, but at the same time mostly researchers agree that a leader and style of leadership plays a critical role in organizational success. Style of leadership performs a considerable function in workers job contentment and his job performance. Employees with greater job satisfaction and commitment have higher job performance [1]. Researchers have paid special attention in finding the connection among style of leadership and job performance.

In recent past one of the mostly researched topics is leader and their style of leadership. Leadership style can be defined as the behavior and methods used by the leaders for giving visualization and the roadmap for reaching that visualization, executions and formulations of plan and strategies [2]. Depending upon situational requirements leadership styles differ from individual to individual [3]. There are numerous leadership theories and all these theories in some different way enlighten the leadership process [3]. Trait, behavioral and contingency theories are considered traditional theories among leadership theories, whereas transformational theory is considered as emerging leadership theory. Transformational leadership is getting more attention and popularity amongst management researchers.
At the same time the connection between style of leadership and employee job performance has received significant attention of researchers. Scholars have highlighted that an employee with high commitment has high job performance [1]. To stay in competition in competitive world, leading organizations have focused more on employee's job performance [4]. It is assumed that success of any organization depends upon efficient leadership and better harmonization among leaders and workers. Role of leader is to guide their organization in fulfilling their tasks, operations and goals. Researchers have highlighted that job performance is mostly dependent upon leadership style. Focus of this study will be to find out the transformational leadership influence on workers job performance in Pakistan health sector. It is discussed that method of transformational management encourages their employees to perform much better than expected and produce much better outcome as compared to those employees who are governed by those leaders who adopt technique of transactional leadership style [3]. According to Bass et al. [5] transformational leadership has four behavioral components, which are Individual consideration, Idealized influence, Inspirational motivation and Intellectual stimulation [6]. In hospitals, educational institutes and informational technology based organizations, it is believed transformational leadership has positive impact on their employee's performance and job satisfaction. Transactional leadership style has no impact in this competitive atmosphere, where novelty, creativity and inventiveness are the basic necessities for success of any organization $[7,8]$. Therefore the main center of attention of this research will be to determine transformational leadership relationship with employee's job performance while job satisfaction as mediator in health sectors in Pakistan.

In this study leaders of health sector i.e., doctors, nutritionists and supporting staff of hospitals of Rawalpindi, Islamabad and Lahore were included. Transformational leadership and Job performance of health sector doctors, nutritionists' officers and supporting staff of hospitals were measured. The intention of this study was to create a research model which examines the relation among transformational leadership 
and employee performance while job satisfaction as mediator in health sector of Pakistan.

\section{Literature Review}

Researchers have diversity of opinion about leadership role and its impact on success or failure of any organization. Mostly researchers agree on the pivotal role of leadership style in success of any organization. In past numerous theories have been developed regarding leadership and their styles. In beginning as per trait theory, it was initially it was assumed that leaders are by birth and they cannot be built but then few researchers offered a new theory named behavioral theory. As per behavioral theory leaders have some traits and behavior which turn them into successful leaders. After this few scholars presented contingency theory. According to contingency theory leaders have multiple traits ad behaviors which they apply according to situation and circumstances and not a single trait or behavior as highlighted in behavioral theory. But at present transformational leadership theory is getting recognition amongst management researchers and scholars.

In recent history the most researched topic is about leaders and style of leadership.

Leadership styles consist of techniques, behaviors and methods implemented by leaders to present roadmap and vision for formulating and executing their strategic and tactical plans

House et al. [2] style of leadership differs from individual to individual. Moreover leadership style is dependent upon need of situations and circumstances [5]. As earlier discussed, there are quite a few leadership theories and all these theories enlighten process of leadership in various ways [5]. Amongst leadership theories, few are considered traditional and few modern theories. Trait, contingency and behavioral theories are considered traditional leadership theories, whereas transactional and transformational theories are considered modern theories of leadership. Over period of time traditional leadership theories (Trait, behavioral and contingency Theory) have been developed. Each of the traditional theory highlights some diverse leadership dimensions and also explains connection amongst leader and follower in different ways [5].

\section{Relation among transformational leadership and employee performance}

Mainly transformational leadership is extensively explored technique of leadership. Moreover, results of previous researches indicate a positive association exists among transformational leadership technique and organizational effectiveness [9]. Leaders having transformational leadership traits are very zealous, passionate, motivated and energetic. Transformational leaders put all their effort to enhance the abilities, potentials, ethics and trust of their followers. Transformational leaders express and converse a persuasive visualization to their employees that encourage, motivates and inspire them to accomplish unexpected objectives and targets [10]. Leaders with transformational abilities are honest, straight and demonstrate uprightness. They always lay down clear objectives and communicate these objectives to their employees and share their vision with them [3]. It is discussed that transformational leadership flourishes in environments where leaders and their employees are positively engaged for organizational betterment [11].
Transformational leaders do not only augment the abilities, competences and skills of their employees but also align employee's objectives with organizational objectives. In numerous studies it was found that employee's obligation towards their organization and work performance is positively associated with technique of transformational leadership [12]. Transformational leaders have capability to display transactional leadership style according to situation therefore transformational leadership is not considered a totally dissimilar leadership from transactional leadership but it is assumed to be an extension of transactional leadership [13,14]. Walumbwa et al. [15] highlighted that transformational leadership had direct impact on managerial performance in banking sector. A large numbers of researches have explored and examined the influence of transformational leadership technique on work performance in different sectors [16-19].

Job performance of an employee increases with greater job satisfaction and job commitment [1]. The most important function of any organization is to enhance his job employee's performance so that it could compete in highly competitive atmosphere. Numerous representation and theories have been offered to ascertain a connection among the style of leadership and work performance $[20,21]$. Leaders put all their effort to offer full encouragement and support to their employees. Transformational leaders with greater individual thoughts and kindness are better trainer / guide and have ability to connect the employee's objectives with organizational objectives [22]. Passage of time transformational leaders has proved to be helpful and fruitful in variety of hospitals, educational institutes and businesses linked with informational technology. Past research work has established that transformational leadership technique is interlinked with employee's job satisfaction and productivity. In present competitive scenario, where basic requirement for organizational success is creativity and innovation, therefore, transactional leadership style has become less effective [7,23]. Every leadership style has his own influence and results in terms of employee performance [24].

Hypothesis 1: Transformational leadership has positive impact on Employee performance.

Voon et al. [25] defined job satisfaction as an individual mind-set towards his job. Job contentment is a pleasant or positive emotional state of mind which comes out from the assessment of an individual work or professional skills [26]. Voon et al. [25] highlighted that employees feel more content with their work if realize that their work is satisfying and rewarding. Job satisfaction ultimately influences the work performance and success of organization [27]. Contentment towards job is optimistic emotional state of mind which results from individual's job or skills [28].

\section{Transformational leadership association with job satisfaction}

Leadership technique has an important role and impact on worker job contentment [29]. Researchers discovered that different leadership styles have different influences on employee's job satisfaction under different working conditions $[25,29,30]$. Voon et al. [29] indicated that transformational leadership style could fundamentally increase job contentment, being capable to communicate sense of responsibility, task and intellectual inspiration. Generally leaders adopting transformational technique have capability to inspire their employees to become more autonomous and accountable [31] which resultantly increase workers job contentment and sense of accomplishment. 
Hypothesis 2: Transformational leadership has positive impact on job satisfaction.

\section{Job satisfaction association between employee performance and job satisfaction as mediator among transformational leadership and employee performance}

Job satisfaction increases employee performance [28]. Furthermore, Mangkunegara [30] and Mujkic et al. [29] highlighted that when employees are more contented with their job, their interest to accomplish their assigned tasks also enhances. Rezvani et al. [28] indicated that when employees are contented with their work, they are likely to perform better and also to perform decision making and problem solving more effectively. Supporting this argument, Fisher [32] suggested that employees with lower job contentment will have lower performance, because discontented employees have lesser enthusiasm to perform their work and as result of this they do not put all their efforts and hard work. Furthermore, employees with lower job contentment will handle the assigned tasks and responsibilities with less enthusiasm and keenness [33].

By adopting appropriate leadership style, managers can have an impact on employee's commitment, productivity, efficiency and job contentment. Leadership style can be witnessed as series of supervisory behavior, characteristics, conduct, and ability based on employee as well as standards of organizations $[25,26]$.

Leadership performs vital and dominant role in achieving job satisfaction. Leadership is measured as function of management, which generally focuses public relations, people, and techniques to inspire people for achieving higher performance and organizational success $[25,30]$. Several researches carried out in various countries indicated that transformational leadership technique has positive correlation with job contentment which eventually has output in shape of higher employee performance and achieving organizational success [34,35].

On above mentioned point of view, research recommends that transformational leadership technique helps in enhancing job fulfillment and as result workers performance will also be enhanced (Figure 1). Therefore, job contentment may act as mediator in the connection between technique of transformational leadership and employee performance [36]. However, it is significant to examine this relationship; reasonably less research work has highlighted team processes such a steam-building as mediator among transformational leadership connection with employee performance [37]. Hence, following hypothesis is offered:

Hypothesis 3: Job satisfaction has positive impact on employee performance.

Hypothesis 4: Job satisfaction has positive mediation role among transformational leadership and employee performance.

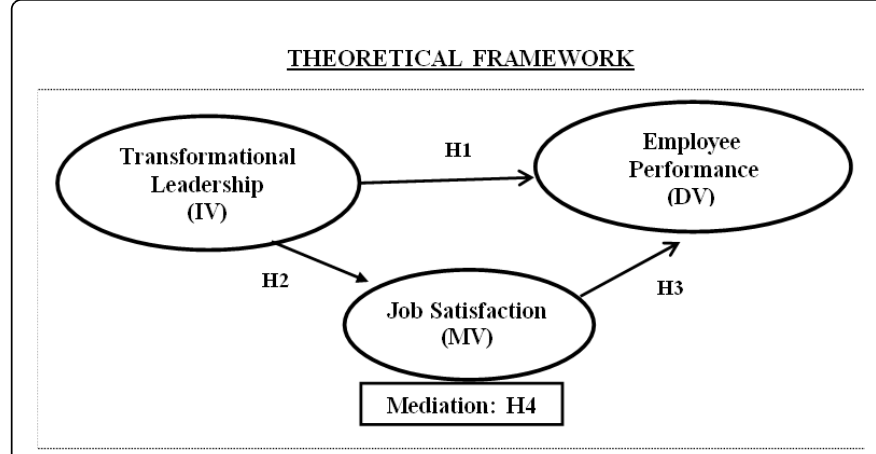

Figure 1: Conceptual Framework of the Study.

Above mentioned research model highlights association between transformational leadership Independent Variable (IV), employee performance Dependent Variable (DV) and job satisfaction Mediating Variable (MV). Model indicates that transformational leadership has positive influence on employee performance and job satisfaction. Job satisfaction is positively influencing employee performance, basing upon this $\mathrm{H} 1, \mathrm{H} 2$ and $\mathrm{H} 3$ are offered.

\section{Research Methodology}

The objective of this study is to establish the impact of transformational leadership on employee performance with job satisfaction of doctors, health nutrition officers, medical technicians and other supportive staff of hospitals working in health sector located in Lahore, Islamabad and Rawalpindi as mediator. Data was collected by using questionnaire method. Transformational leadership (IV) questionnaire was adopted from Wang et al. [19] Transformational leadership questionnaire consisted of 6 items and five point Likert scale from $1=$ Strongly Disagree to $5=$ Strongly Agree was used to quantify this variable. Job satisfaction (Mediating Variable) questionnaire was adopted from Judge et al. [17] Job satisfaction questionnaire consisted of 5 items and same five point Likert scale from 1=Strongly Disagree to $5=$ Strongly Agree was used to quantify this variable. Employee performance (DV) questionnaire was adopted from Salanova, Marisa, Jose Maria Peiro, and Sonia Agut. Employee performance questionnaire consisted of 6 items and five point Likert scale from $1=$ Worst to $5=$ Excellent was used to quantify this variable.

For checking questionnaire reliability and validity, firstly 30 questionnaires were disseminated for pilot testing (Table 1). After pilot testing details reliability data of each variable is shown as under:

\begin{tabular}{|l|l|}
\hline Variable & Cronbach Alpha \\
\hline Transformational Leadership $\quad(T L)$ & 0.877 \\
\hline Job Satisfaction $\quad(J S)$ & 0.620 \\
\hline Employee Performance $\quad(E P)$ & 0.733 \\
\hline
\end{tabular}

Table 1: Pilot testing details reliability data of each variable.

Keeping in view research targets, hospitals located in Lahore, Islamabad and Rawalpindi were chosen as research population. Doctors, health nutrition officers, medical technicians and other supportive staff of hospitals located in Lahore, Islamabad and Rawalpindi were contacted on personal contact basis and according to 
Citation: Naeem S, Khanzada B (2018) Role of Transformational Leadership in Employee's Performance with Mediating Role of Job Satisfaction in Health Sector of Pakistan. J Health Educ Res Dev 6: 245. doi:10.4172/2380-5439.1000245

Page 4 of 6

subject significance. Personally administered questionnaire were disseminated among 250 employees and of those 174 questionnaires were received back but only 152 filled questionnaires were found correctly and completely filled (Table 2). Response rate turns out to be $60.8 \%$.

\begin{tabular}{|l|l|l|l|}
\hline \multirow{4}{*}{ Gender } & & Frequency & Percentage \\
\hline \multirow{5}{*}{ Qualification } & Male & 113 & $74.3 \%$ \\
\cline { 2 - 4 } & Female & 39 & $25.7 \%$ \\
\cline { 2 - 4 } & MBBS & 63 & $41.4 \%$ \\
\hline \multirow{5}{*}{ Age } & M Phil /Others & 5 & $55.3 \%$ \\
\hline \multirow{5}{*}{ Experience } & $25-30$ & 86 & $3.3 \%$ \\
\cline { 2 - 4 } & $31-40$ & 54 & $56.6 \%$ \\
\cline { 2 - 4 } & $41-50$ & 10 & $35.5 \%$ \\
\cline { 2 - 4 } & $51-60$ & 2 & $6.6 \%$ \\
\cline { 2 - 4 } & $0-2$ yrs & 51 & $1.3 \%$ \\
\cline { 2 - 4 } & $3-5$ yrs & 74 & $33.6 \%$ \\
\cline { 2 - 4 } & $6-10$ & 11 & $48.7 \%$ \\
\cline { 2 - 4 } & Above 10 yrs & 16 & $10.5 \%$ \\
\hline
\end{tabular}

Table 2: Demographic Analysis.

A survey was carried out for testing research model. Sample size of data was $152.74 .3 \%$ of respondents of this study were found male and $25.7 \%$ female. Furthermore, 56.6\% respondents were found among 20-30 years age group, 31-40 years age group respondents were $35.5 \%$, $6.6 \%$ of respondents were among $41-50$ years and $1.3 \%$ were among 51-60 years. According to qualification $41.4 \%$ respondents were MBBS, $55.3 \%$ respondents were FCPS degree holders and 3.3\% of the respondents belonged to $\mathrm{M}$ Phil /others category. 0-2 years' experience respondents comprised 33.6\%, 3-5 years experienced respondents were $48.7 \%$, 6-10 years experienced respondents comprised 7.2\%, whereas, $10.5 \%$ of the sample showed respondents having experience above 10 years.

\section{Results}

Results and findings of research study are discussed as under (Table $3)$. Moreover, in analysis part correlation and regression analysis were conducted.

\begin{tabular}{|l|l|l|l|}
\hline Variables & $\mathbf{1}$ & $\mathbf{2}$ & $\mathbf{3}$ \\
\hline Transformational Leadership & 1 & & \\
\hline Job Satisfaction & $0.234^{* *}$ & 1 & \\
\hline Employee Performance & $0.593^{* *}$ & $0.350^{* *}$ & 1 \\
\hline $\begin{array}{l}{ }^{*} \mathrm{p}=0.05,{ }^{* *} \mathrm{p}=0.01 \\
{ }^{* *} \text { Correlation is significant at the } 0.01 \text { level (2-tailed) }\end{array}$ \\
\hline
\end{tabular}

Table 3: Correlation.
In Table 2 correlation analysis shows the association between independent, dependent and mediation variables which are transformational leadership (IV), job satisfaction (Mediator) and employee performance (DV). Transformational leadership correlated job satisfaction by $0.234^{\star *}$, which shows positively significant correlation among both variables. Transformational leadership technique and employee performance correlated by $0.593^{* *}$, which highlights a positive significant correlation among both variables. In the same way, correlation among job satisfaction and employee performance found $0.350^{* *}$, which establishes positive significant correlation among both variables (Table 4 ).

\begin{tabular}{|l|l|l|l|}
\hline \multirow{2}{*}{ Predictor } & \multicolumn{3}{l|}{ Outcome Employee Performance } \\
\cline { 2 - 4 } & $\boldsymbol{\beta}$ & $\mathbf{R}^{2}$ & $\Delta \mathbf{R}^{2}$ \\
\hline Step I Control Variables & & 36 & 036 \\
\hline Step II Job Satisfaction & 0.223 & 0.148 & 0.112 \\
\hline Step III Transformational Leadership & 0.541 & 0.413 & 0.265 \\
\hline a. Predictors: (Constant), Age, Experience, Gender, Qualification \\
\hline b. Predictors: (Constant), Age, Experience, Gender, Qualification, JSM \\
\hline c. Predictors: (Constant), Age, Experience, Gender, Qualification, JSM, TLM \\
\hline
\end{tabular}

Table 4: Mediation Regression Analysis.

Barron and Kenny mediation aggression analysis results were highlighted in Table 3. Results indicate significance among direct association among transformational leadership and worker performance. After incorporating job satisfaction as mediator, change in $\mathrm{R}^{2}$ comes about at 0.112 which is considerable, thus highlighting that job satisfaction mediates connection among transformational leadership (IV) and employee performance (DV), which leads towards hypothesis 4 acceptances (Table 5).

\begin{tabular}{|l|l|l|}
\hline $\boldsymbol{\beta}$ & $0.1682^{* \star}$ & $\mathbf{t}$ \\
\hline TL to JS (a) (IV to Mediator) & 3.0615 \\
\hline JS to EP (b) (Mediator to DV) & $0.3135^{\star *}$ & 3.0896 \\
\hline TL to EP (c) (IV to DV) & $0.6123^{\star \star}$ & 8.8530 \\
\hline TL to EP (c') (IV to DV) & $0.5595^{* \star}$ & 8.0678 \\
\hline
\end{tabular}

Table 5: Mediation. ${ }^{*} \mathrm{p}=0.05 ;{ }^{*} \mathrm{p}=0.01$.

Indirect process analysis results are highlighted in Table 4. Result shows that job satisfaction partially mediates the association among transformation leadership and employee performance, which leads towards recognition of hypothesis 4 .

\section{Discussion}

The idea of this research was to discover the association among transformational leadership (IV) and employee performance (DV) through job satisfaction as mediator. As predicted, it was established that transformational leadership (IV) plays a significant role in employee performance (DV). Transformational leadership qualities inspire influences and motivate employees towards higher performance, through their job satisfaction. Current research this 
finding concurs the preceding literature which highlights that transformational leadership has a positive association with employee performance [26,38-41] which leads towards recognition of Hypothesis 1. According to research, if managers adopt transformational leadership techniques, they will augment employer efficiency which leads towards acceptance of $\mathrm{H} 1$.

Hypothesis 2 tested the positive association of transformational leadership with job satisfaction, which was also acknowledged. This result is also similar with earlier studies and literature. Transformational leadership techniques will assist to make sure workers job contentment which will in turn will ensure elevate workers performance. After this research it can be highlighted that worker job contentment will occur if leader is successful in applying his transformational leadership skills. This research finding is similar to earlier studies which also highlighted that transformational leadership techniques enhances job contentment [6,25,29-31,42-44]. Furthermore, all other results are also similar and aligned with earlier studies which indicated that job satisfaction has a positive impact upon worker/employee performance. When workers will be more contented with their work, they are going to execute their work with more keenness and devotion to make sure successful execution of allocated work $[28-30,32,45]$.

Mediation hypothesis reflected that association between transformational leadership and workers performance is mediated by job satisfaction. Results lead to the recognition of hypothesis and also similar to earlier literature. Existing literature recognized that job contentment is observed as vital factor in enhancing manager's competence, effectiveness and his transformational leadership techniques to augment worker's job contentment as well as his effectiveness towards his work which may lead to workers performance $[26,30,34,37,46-49]$.

\section{Theoretical and Practical Implications}

This research adds in literature of management and health sectors by incorporating transformational leadership and job satisfaction as research model. Results of this research highlights that job satisfaction mediates among transformational leadership and employee proficiency. This research augments our perceptive towards transformational leadership techniques and job contentment in enhancing employee performance. As expected, transformational leadership was significantly associated with employee performance, in both ways (with and without incorporating job satisfaction as mediator). This study helps in disclosing the ways how transformational leadership qualities and techniques can complement the workers performance by exhibiting importance of job satisfaction as mediator. By adopting transformational leadership helps in developing job contentment among workers, which resultantly increases workers performance. This indicates that transformational leadership positively affects the workers performance and employee's performance will enhance if organizations also adds in promoting job contentment among their workers. This research finding indicates job satisfaction effects as mediator have partial effect, which means that there are other variables which have an impact on transformational leadership and employee performance association.

Few more implications can also be extorted from the results such as Doctors, health nutrition officers; medical officer's transformational leadership quality augments their performances through job contentment. This finding is aligned with previous research indicating positive association among transformational leadership and employee performance $[40,41]$. One more practical implication of this research is that doctors, health nutrition officers, medical officers should be given training regarding transformational leadership techniques which will augment their performance and firm's performance. This also includes that transformational leadership training must focus on rising job contentment among employees for achieving utmost results and benefits.

\section{Limitations and Directions for Future Research Directions}

This research has quite a few limitations which needs deliberation while understanding findings. Firstly considering time constraint, comparatively little sample was gathered from hospitals located at Lahore, Rawalpindi and Islamabad only. Consequently, if in future data collected from all over the country with a bigger sample size will overcome this limitation. Moreover, it will also present a comprehensive and inclusive depiction.

Data compilation method is the second limitation. Since questionnaire method was the only technique used in collection of data gathering. Therefore, it is suggested that future research should assemble data using multiple techniques.

Time constraint is the third limitation of this research. Cross sectional data was gathered using convenience sampling technique. Therefore, other recommendation is that for future research work, time lag method should be used while gathering data.

Although, research objectives have been achieved but still in future after integrating more relevant variables associated to employee performance and results assessment regarding job satisfaction on overall workers performance and performance of the organization can further explain the association.

\section{References}

1. Walumbwa FO, Hartnell CA (2011) Understanding transformational leadership employee performance links: The role of relational identification and self-efficacy. Journal of Occupational and Organizational Psychology 84: 153-172.

2. House RJ, Aditya RN (1997) The social scientific study of leadership: Quovadis?. Journal of Management 23: 409-473.

3. Bass BM, Bass R (2009) The Bass handbook of leadership: Theory, research, and managerial applications: Simon and Schuster.

4. Wofford JC, Whittington JL, Goodwin VL (2001) Follower motive patterns as situational moderators for transformational leadership effectiveness. Journal of Managerial 13: 196-211.

5. Bass BM, Avolio BJ (1990) Transformational leadership development: Manual for the multifactor leadership questionnaire: Consulting Psychologists Press, Palo Alto, CA, p: 65.

6. Bass BM (1999) Two decades of research and development in transformational leadership. European Journal of Work and Organizational Psychology 8: 9-32.

7. Bass BM (1998) Transformational leadership: Industry, military, and educational impact: Mahwah. NJ: Erlbaum, p: 208.

8. Masi RJ, Cooke RA (2000) Effects of transformational leadership on subordinate motivation, empowering norms, and organizational productivity. International Journal of Organizational Analysis 8: 16-47.

9. Brand C, Heyl G, Maritz D (2000) Leadership In Organizational Development and Transformation in South Africa. Durban: Butterworths. 
10. Cacioppe R (1997) Leadership moment by moment!. Leadership \& Organization Development Journal 18: 335-345.

11. Burns JM (2003) Transforming leadership: A new pursuit of happiness. Grove Press, p: 35.

12. Arnold KA, Barling J, Kelloway EK (2001) Transformational leadership or the iron cage: which predicts trust, commitment and team efficacy? Leadership \& Organization Development Journal 22: 315-320.

13. Bass BM (1997) Personal selling and transactional/transformational leadership. Journal of Personal Selling \& Sales Management 17: 19-28.

14. Ristow AM, Amos TL, Staude GE (1998) Transformational leadership and organizational effectiveness in the administration of cricket in South Africa. Unpublished M Comm Thesis. Grahams Town: Rhodes University 30: $1-5$.

15. Walumbwa FO, Avolio BJ, Zhu W (2008) How transformational leadership weaves its influence on individual job performance: The role of identification and efficacy beliefs. Personnel Psychology 61: 793-825.

16. Liao H, Chuang A (2007) Transforming service employees and climate: a multilevel, multisource examination of transformational leadership in building long-term service relationships. Journal of Applied Psychology 92: 1006-1019.

17. Schaubroeck J, Lam SS, Cha SE (2007) Embracing transformational leadership: team values and the impact of leader behavior on team performance. Journal of Applied Psychology 92: 1020-1030.

18. Judge TA, Piccolo RF (2004) Transformational and transactional leadership: a meta-analytic test of their relative validity. Journal of Applied Psychology 89: 755-768.

19. Wang H, Law KS, Hackett RD, Wang D, Chen ZX (2005) Leader-member exchange as a mediator of the relationship between transformational leadership and followers' performance and organizational citizenship behavior. Academy of Management Journal 48: 420-432.

20. Vigoda-Gadot E (2007) Leadership style, organizational politics, and employees' performance: An empirical examination of two competing models. Personnel Review 36: 661-683.

21. Pedraja-Rejas L, Rodríguez-Ponce E, Delgado-Almonte M, RodríguezPonce J (2006) Transformational and transactional leadership: a study of their influence in small companies liderazgo transformacional y transaccional: un estudio de su influencia en las pequeñas empresas. Ingeniare 14: 159-166.

22. Horwitz IB, Horwitz SK, Daram P, Brandt ML, Charles Brunicardi F, et al. (2008) Transformational, transactional, and passive-avoidant leadership characteristics of a surgical resident cohort: analysis using the multifactor leadership questionnaire and implications for improving surgical education curriculums. Journal of Surgical Research 148: 49-59.

23. Masi RJ, Cooke RA (2000) Effects of transformational leadership on subordinate motivation, empowering norms, and organizational productivity. International Journal of Organizational Analysis 8: 16-47.

24. Yammarino FJ, Spangler WD, Dubinsky AJ (1998) Transformational and contingent reward leadership: Individual, dyad, and group levels of analysis. The Leadership Quarterly 9: 27-54.

25. Voon ML, Lo MC, Ngui KS, Ayob NB (2011) The influence of leadership styles on employees' job satisfaction in public sector organizations in Malaysia. International Journal of Business, Management and Social Sciences 2: 24-32.

26. Shahzad N, Benish K (2017) Impact of Transformational Leadership in Attainment of Project Success: The Mediating Role of Job Satisfaction. International Journal of Business and Social Science 8: 168-177.

27. Belias D, Koustelios A (2014) Transformational leadership and job satisfaction in the banking sector: A review. International Review of Management and Marketing 4: 187-200.

28. Rezvani A, Chang A, Wiewiora A, Ashkanasy NM, Jordan PJ, et al. (2016) Manager emotional intelligence and project success: The mediating role of job satisfaction and trust. International Journal of Project Management 34: 1112-1122.
29. Mujkic A, Sehic D, Rahimic Z, Jusic J (2014) Transformational leadership and employee satisfaction. EkonomskiVjesnik / Econviews: Review of Contemporary Business, Entrepreneurship and Economic issues 27: 259-270.

30. Mangkunegara AAP (2016) The Effect of Transformational Leadership and Job Satisfaction on Employee Performance. Universal Journal of Management 4: 189-195.

31. Long CS, Yusof WMM, Kowang TO, Heng LH (2014) The impact of transformational leadership style on job satisfaction. World Applied Sciences Journal 29: 117-124.

32. Fisher CD (2003) Why do lay people believe that satisfaction and performance are correlated? Possible sources of a commonsense theory. Journal of Organizational Behavior 24: 753-777.

33. Judge TA, Thoresen CJ, Bono JE, Patton GK (2001) The job satisfactionjob performance relationship: a qualitative and quantitative review. Psychological Bulletin 127: 376-407.

34. Berson Y, Linton JD (2005) An examination of the relationships between leadership style, quality, and employee satisfaction in $R \& D$ versus administrative environments. R\&D Management 35: 51-60.

35. Seo Y, Ko J, Price JL (2004) The determinants of job satisfaction among hospital nurses: a model estimation in Korea. International Journal of Nursing Studies 41: 437-446.

36. Kozlowski SW, Ilgen DR (2006) Enhancing the effectiveness of workgroups and teams. Psychological Science in The Public interest 7: 77-124.

37. Chou HW, Lin YH, Chang HH, Chuang WW (2013) Transformational leadership and team performance: the mediating roles of cognitive trust and collective efficacy. SAGE Open 3: 1-10.

38. Zwikael O, Unger-Aviram E (2010) HRM in project groups: the effect of project duration on team development effectiveness. International Journal of Project Management 28: 413-421.

39. Yang LR, Huang CF, Wu KS (2011) The association among project manager's leadership style, teamwork and project success. International Journal of Project Management 29: 258-267.

40. Aga DA, Noorderhaven N, Vallejo B (2016) Transformational leadership and project success: The mediating role of team-building. International Journal of Project Management 34: 806-818.

41. Anantatmula VS (2010) Project manager leadership role in improving project performance. Engineering Management Journal 22: 13-22.

42. Cavazotte F, Moreno V, Bernardo J (2013) Transformational leaders and work performance: the mediating roles of identification and self-efficacy. BAR-Brazilian Administration Review 10: 490-512.

43. Felfe J, Schyns B (2006) Personality and the perception of transformational leadership: The impact of extraversion, neuroticism, personal need for structure, and occupational self-efficacy. Journal of Applied Social Psychology 36: 708-739.

44. Niehoff BP, Enz CA, Grover RA (1990) The impact of top-management actions on employee attitudes and perceptions. Group \& Organization Studies 15: 337-352.

45. Cheung SO, Ng TS, Wong SP, Suen HC (2003) Behavioral aspects in construction partnering. International Journal of Project Management 21: 333-343.

46. Skansi D (2000) Relation of managerial efficiency and leadership stylesempirical study in Hrvatska elektroprivreda D.D. Management 5: 51-67.

47. Vance C, Larson E (2002) Leadership research in business and health care. Journal of Nursing Scholarship 34: 165-171.

48. Chiok Foong Loke J (2001) Leadership behaviours: effects on job satisfaction, productivity and organizational commitment. Journal of Nursing Management 9: 191-204.

49. Martin BJ (1990) A successful approach to absenteeism. Nursing Management 21: 45-48. 